See discussions, stats, and author profiles for this publication at: https://www.researchgate.net/publication/327160788

\title{
Is there Value Creation in the Banks listed in the Dow Jones Sustainability
} Index Europe?

Conference Paper · June 2018

CITATIONS

0

1 author:

2. Irene Arraiano

Lisbon Polytechnic Institute, Lisbon Accounting and Business School (ISCAL)

9 PUBLICATIONS 17 CITATIONS

SEE PROFILE

Some of the authors of this publication are also working on these related projects:

Prject $\quad$ Sustainability in Europe View project

Project Sustainability in Europe View project
READS

22 


\title{
Is there Value Creation in the Banks listed in the Dow Jones Sustainability Index Europe?
}

\author{
Irene Guia Arraiano \\ Lisbon Accounting and Business School, Lisbon Polytechnic Institute, Portugal, \\ iarraiano@iscal.ipl.pt
}

\begin{abstract}
The banking sector since 2001 has seen an increasing evolution in the number of banks that engage in sustainability in Europe, however, this evolution has been slower when compared to the other sectors of activity. It should be noted that the number of empirical studies in this particular sector in this region covering a specific period of study, which includes the global financial crisis, is scarce. In this sense, the present study evaluates the value relevance of banks listed in the Dow Jones Sustainability Index Europe using a sample of 66 European banks in the stock markets of France, Germany, Italy, the Netherlands, Norway, Spain and the United Kingdom. From 2001 to 2013, the period under review presented a major growth in sustainable investments, by considering the global financial crisis, it was studied in two subperiods, pre and post crisis. Therefore, by using a modified Ohlson model and applying a panel data methodology for the empirical research, consisting of a combination of time series and cross-sectional data in a joint test, it enabled to control individual unobservable heterogeneity as well as the endogenous nature of the explanatory variables. The study found that banks listed in this index are associated with higher market valuations and has a direct effect on stock prices by modifying the value-relevance of financial information. The global financial crisis has led investors to pay attention to sustainability in the banking sector in the European markets and began to include ethical principles in their investment strategies. These findings have important information for both investors and stakeholders, as well as market regulators and policymakers. The present empirical study contributes to the existing literature and encourages investors to play an important role in the sustainable development of such an important sector of society.
\end{abstract}

Keywords: Sustainable development; market valuation; banking sector; financial crisis 